\title{
Septic tanks for residential houses: comparative constructional requirements
}

\author{
Sergey Pavlov ${ }^{1,}$, Valeria Polyakova ${ }^{1}$, Maria Zhukova ${ }^{1}$ and Elena Matys ${ }^{2}$ \\ ${ }^{1}$ Peter the Great St.Petersburg Polytechnic University, Polytechnicheskaya, 29, St.Petersburg, 195251, \\ Russia \\ ${ }^{2}$ Tyumen Industrial University, Volodarskogo str., 38, Tyumen, 625000, Russia
}

\begin{abstract}
In this work the main terms and conceptions are defined. There are a short description of operating principle of anaerobic septic tank, its application conditions, advantages, and disadvantages. This article also introduces requirements for anaerobic septic tank's construction as one of the autonomic systems of sewage water treatment. Article contains the list of documents, which should be delivered with anaerobic septic tank. Article represents descriptions of septic tanks' constructions, which are popular in Russia, with their cost, sizes and value of purification rates of grey water. This research includes conformance review of construction and documents, with the conclusion about the real opportunities and advantages of septic tanks, which are declared by its manufacturers.
\end{abstract}

\section{Introduction}

In last several years, the problem of grey water is becoming more urgent in the world and in Russia particularly. Modern society consume a great volume of water due to their economical activities. The main part of consummated water become polluted, also by organic reasons $[1,2]$. Polluted water could make a harm to the environment, that's why the main part of grey water should be treated [3-5]. Adequate state of purification could be provided by using special equipment and technical complexes, which can decrease pollution to values most closely approximated to standard.

Modern septic tanks could be divided into following groups by operation principle:

1. septic tanks;

2. aerating purifiers [1].

This research analyze the first group. The goals of this research was:

1. formation of the main requirements for septic tanks construction;

2. creation of the suggestion about list of documents that should follow the product;

3. comparison of the overseas and home-produced septic tanks by next points:

3.1. main requirements for constructions;

3.2. existence of documents explaining construction opportunities;

3.3. level of purifying;

3.4. cost;

* Corresponding author: coolhabit@yandex.ru 
3.5. convenience in maintenance;

3.6. sixes and weight;

3.7. cost per one person.

Septic tank is sewage treatment system, which remove pollution of grey water based on assertion and destruction of organic matter by aerobic bacteria. Septic tank by itself is not the finished sewage purification construction; it should be used by standards as the first step of treatment. Usually grey water incurs the process of additional purifying after the purification by septic tank $[1,6]$. It should be noted that in popular publications all types of sewage purification constructions are called as septic tanks [7]. The most complete publication, where only anaerobic water treatment systems are called septic tanks or digestion tanks, was taken as a methodical basis of this article.

\section{Materials and methods}

Digestion tanks have some usage restrictions [1], such as:

- Installation is possible only with the low level of groundwater (their level should not be higher than level of filtration pipes).

- There should be adequate filtration pipes in the area of installing.

- Inflowing grey water should have an adequate level of $\mathrm{pH}$ (anaerobic bacteria are effective only among $\mathrm{pH} 6.5$ and 8.0, so that usage of dishwasher and washing machine is unwanted).

- Grey water must be incurred by additional purifying in filtration field or in aerating sewage system after the septic tank purification.

- Grey water should have the temperature $20^{\circ} \mathrm{C}$ or higher.

- $\quad$ There should be adequate square near the house for filtration field.

Digestion tanks also have some advantages [1,8]:

- Septic tanks are energy independent.

- Absence of winter period stop necessity.

- $\quad$ Reliable while meeting the requirements of operations manual.

The scheme of construction of the easiest digestion tank and filtration field is shown in the Figure 1.

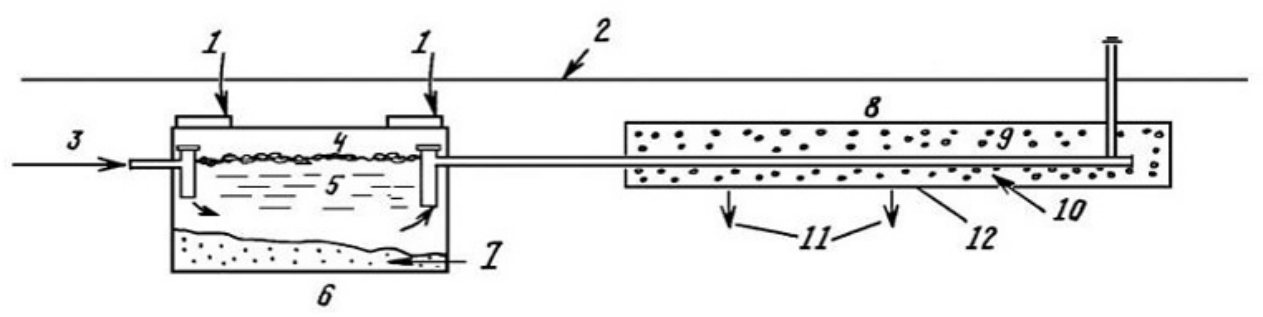

Fig. 1. Sewage treatment in septic tank and additional cleaning on filtrationg field [1].

where: 1 - inspection eye for maintanance and cleaning tank; 2 - soil's surface; 3 - inlet; 4 supernatant pollution; 5 - liquid; 6 - septic; 7 - tankage; 8 - backfilling; 9 - drainage or perforated pipe; 10 - gravel packing; 11 - sewage inleak; 12 - filtrating trench.

According to source [1] septic tank represents reservoir at a ground level and its sizes are established due to the spending time of grey water. Digestion tank should be well heatinsulated by encasing with the insulating material. The top panel can be strewed by the lay of soil with thickness about $0.3 \mathrm{~m}$, which can be digged, if it is necessary to access the interior volume of purifying construction. The inlet and drain pipes have T-shaped tips which prevent stoppage of pipeline by rubbish from the surface of sewage and prevent the air transfer to 
septic tank from connecting pipe working in phreatimetric mode. The functions of digestion tanks are sedimentation of suspension, fat flotation, anaerobic decomposing of organic matter and storage of ooze. Suspension of coarse aggregates is essential for prevention of perforated pipes of system of soils filtration stopping. It is known that septic tanks are economical and practical devices for sewage treatment in areas where soils are unavailable for filtration [9]. In places where usage filtration fields is impossible the additional purifying is needed to achieve an adequate quality of water for chopping it into water course surface. The additional purifying could be achieved by aeration and disinfection. However, these methods are expensive.

Due to purposes of adequate conditions provision authors supposed that the construction of septic tank should meet following requirements:

- In order to prevent the air transferring into septic tank the inlet and drain joining pipe should be T-shaped with fixing flange in top part for convenient cleaning fixing flange. L-shaped fixing flange is also available but it is dangerous to emergent pollution;

- $\quad$ Fixing flanges should be placed just under inspection eye to provide convenient cleaning;

- Inspection eyes should be hermetical and have an opportunity of insulation in top part;

- The height of "wells" of hatches should provide placement of inlet and drain joining pipe lower than frost level;

- The volume of septic tank should correspond to the number of bedrooms in house [1].

Authors proposed following options for product rationality and consumer's confidence in quality of purifying:

- Detailed drawing (or scheme) of product. Sections and axonometric drawings should contain all the details related with hydraulic and biological processes in tank.

- Detailed description of operating principle of product and processes, which taking place in it.

- Explanation of functions and constructions of main parts.

- Justification of using expensive parts that are absent in similar constructions (for example, floating or brush loading, dividing walls etc).

- Official documents from licensed organizations confirming the quality of purifying sewage. Among them are compulsory:

- License from the public authority.

- Text report on purifying sewage with the parameters of original grey water by points from official standards and for output water [10].

\section{Results and discussions}

The authors of the article researched the several types of septic tanks and its characteristics due to the manufacturer's facts [11-15] (Table 1,2).

Table 1. Data from manufacturers.

\begin{tabular}{|c|c|c|c|c|c|}
\hline No & Model & $\begin{array}{c}\text { Producing } \\
\text { country }\end{array}$ & $\begin{array}{c}\text { Degree of } \\
\text { purification, } \%\end{array}$ & $\begin{array}{c}\text { Including the cost of } \\
\text { installation, ruble }\end{array}$ & $\begin{array}{c}\text { Cost per } \\
\text { person, ruble }\end{array}$ \\
\hline 1 & Carat-S & Germany & $60-70 \%$ & 135000 & 27000 \\
\hline 2 & GreenRock 05 & Finland & - & 172900 & 57633 \\
\hline 3 & YES! & Russia & - & 79900 & 15980 \\
\hline
\end{tabular}




\begin{tabular}{|c|c|c|c|c|c|}
\hline 4 & Tank Universal & Russia & $80 \%$ & 70500 & 23500 \\
\hline 5 & Chistock 2500 & Russia & $65,90 \%^{*}$ & 62470 & 15618 \\
\hline
\end{tabular}

Table2. Data from manufacturers.

\begin{tabular}{|c|c|c|c|c|c|}
\hline No & Model & Dimensions, mm & Weight, kg & Volume, liter & Number of users, per \\
\hline 1 & Carat-S & $1600 \times 1690 \times 2015$ & 120 & 2700 & $3-5$ \\
\hline 2 & GreenRock 05 & $1000 \times 1500 \times 1250$ & 70 & 2700 & $1-3$ \\
\hline 3 & YES! & $1100 \times 3000 \times 1100$ & 48 & 2800 & 5 \\
\hline 4 & Tank Universal & $1800 \times 1200 \times 1700$ & 130 & 2600 & $3-4$ \\
\hline 5 & Chistock 2500 & $1300 \times 1100 \times 1980$ & 160 & 2500 & $4-5$ \\
\hline
\end{tabular}

*-manufacturers data from various electronic sources.

Manufacturers guide contains the following graphic material illustrating the device of septic tanks with their rating of devices.

1. Carat-S.

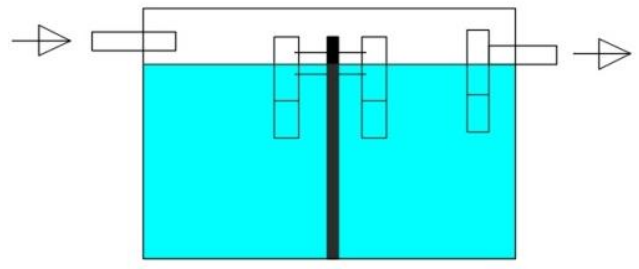

Fig. 2. Carat-S scheme.

This type of septic tank represents a plastic reservoir, which could be divided into 2- or 3 -section. The scheme is shown in the Figure 2 [16].

The characterics of the septic tank are :

- This tanks are made only of quality reinforced polypropylene.

- High strength is determined by strengthening ribs and reinforcement as the result the pressure of soils and groundwater cannot be harmful.

- Long warranty period - 50 years.

- Carat- S could be installed without heavy equipment that make general costs lower.

2. Green Rock 05.

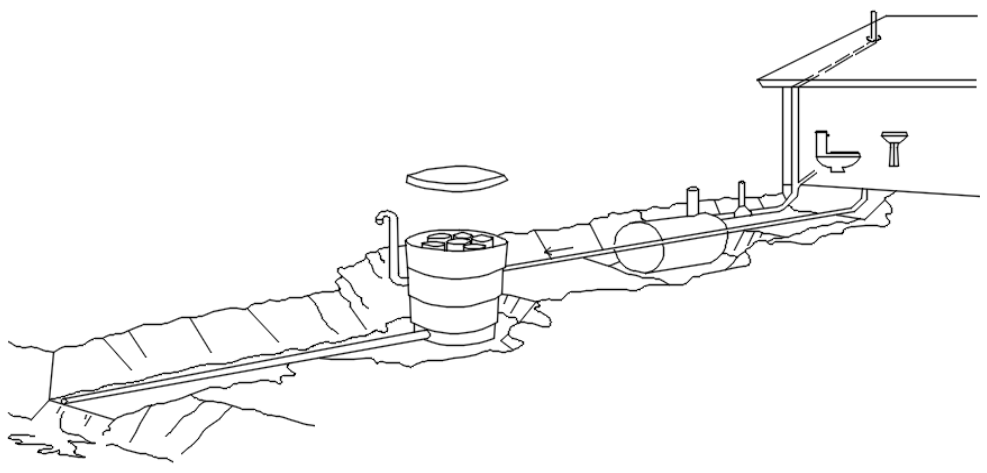

Fig. 3. Appearance Green Rock 05. 
Appearance of Finnish complex is shown in Figure 3. It is the plastic tank of intricate shape divided on 3 sections. The scheme is shown in Figure 4 [11].

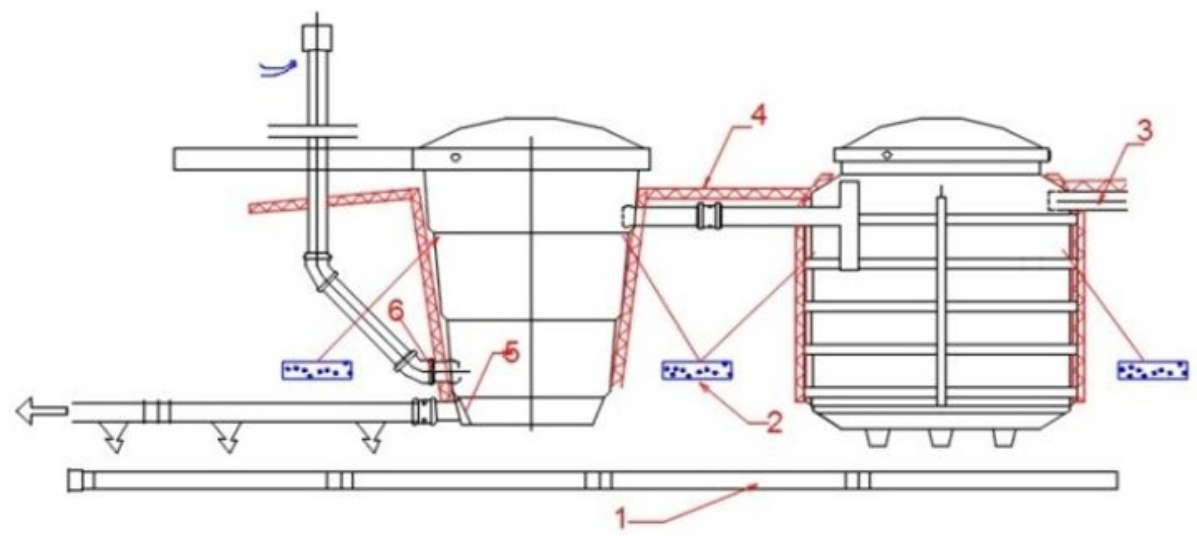

Fig. 4. Green Rock 05 scheme. On picture 4: 1 - drainage; 2 - fixature; 3 - input; 4 - thermal insulation; 5 - output; 6 - aeration.

\section{3. $\underline{\text { YES }}$}

The tank is manufactured in Russia and represents two-section fiberglass reservoir. Its advantages according to manufacturer [17]:

- The framework has special shape with strenthening ribs that in a collaboration with valuable thickness of fiberglass protects the tank from pressure of soil and groundwater.

- The minimal working life is 50 years.

- The cost of YES! is comparatively low.

- The weight of construction is low .

4. Tank Universal 2.

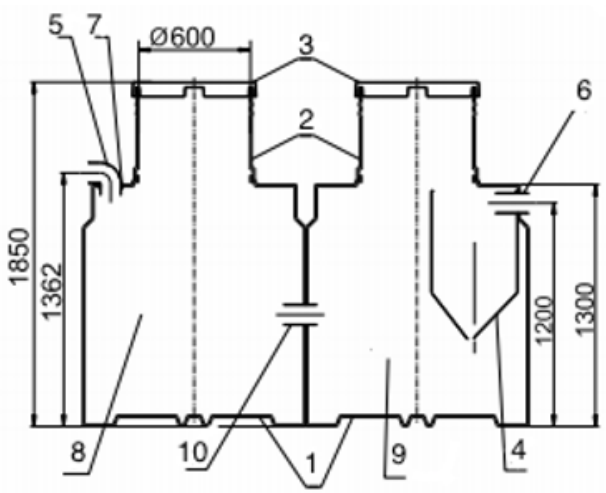

Fig. 5. Tank Universal 2 scheme, where: 1 - body; 2 - filler tube; 3 - lid; 4 - biofilter; 5 - enter brunch; 6 - outer pipe; 7 - sealing; 8 - inlet chamber 1; 9 - chamber 2; 10 - warning pipe.

This model epresents a 2-section plastic reservoir of complicated shape (Figure 5).

Advantages according to manufacturer are:

- The maximum simplicity of construction provides its reliability because there is no nodes that can crash.

- Tank is fully autonomy and could be installed in the areas without stable electricity.

- Installation is comparatively easy. The framework has special shape with strenthening rib and preventive concreting of foundation pit is not nessecary. 
- The septic tank is low-maintanance.

5. Chistock 2500.

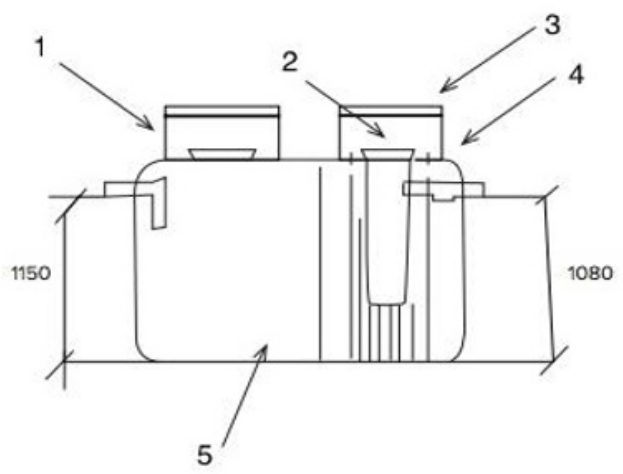

Fig. 6. The scheme of Chistok 2500, where: 1 - ring; 2 - blanking coupler; 3 - inspection eye; 4 - ring; 5 - reservoir 25001.

The construction is represented as a solid-cast heavy-walled plastic tanks divided into 23 sections with different functions.

Advantages according to manufacturer are:

- Resistibility; the material of construction is polyethylene and thick walls are jointfree that guarantees the imperviousness and stability to external loads.

- Ergonomics; construction of tank follows the principle "density+utility+easy to maintain".

- Stable to peak emissions.

- High quality of purification - 2 types of filtration material and extended volume.

- Working life is 50 years.

The authors proposes such an improvements to increase the effectiveness of the reviewed septic tanks.

Carat-S:

- $\quad$ Supplying sewage could not prevent the addition of the supplying air into the tank that decrease the quality of purifying.

- Cleaning of construction is difficult.

Green Rock 05:

- Dirt collector could be more effective if air supply through inlet pipe would be stopped.

- There is no drip irrigation of stocking that provide effective absorption organic pollution by biofilm on a biofilter's scheme.

- The collector for exfoliated biofilm is abscent.

YES!:

- The presented tank is a usual septic tank. Without air supply into construction according to background of alike products, the possible purifying level could be $70 \%$ [18].

Tank Universal 2.0;

- The anaerobic treatment is possible only in inlet chamber (inlet chamber 1 on scheme. Only aggregates collection is possible in the camera with biofilter. Anaerobic treatment is impossible because of supplying air in inlet junction pipe [19].

Chistock 2500:

- The presented tank is a usual dirt collector. It could not work as an anaerobic septic tank because air can freely get into the construction from the air pipe near the outlet junction pipe connected with infiltrator or filtration field with aerating pipes. 
- The effectiveness of the biofilter based on "Waterweed" is low because anaerobic bacteria will be inhibit by oxygen from outlet junction pipe.

According to these materials, authors composed the table allowing to measure matching constructions of those anaerobic septic tanks in order to meet the requirements (Table 3 ).

Table 3. Compliance with the instructions. Compliance with the requirements.

\begin{tabular}{|c|c|c|c|c|c|c|}
\hline \multirow{2}{*}{$№$} & \multirow{2}{*}{ Name septic tank } & \multicolumn{5}{|c|}{ Requirement } \\
\cline { 3 - 7 } & & 1 & 2 & 3 & 4 & 5 \\
\hline 1 & Carat-S & - & - & + & + & $?$ \\
\hline 2 & Green Rock 05 & \pm & + & + & - & $?$ \\
\hline 3 & YES & + & + & + & + & $?$ \\
\hline 4 & Tank Universal 2 & \pm & + & + & - & $?$ \\
\hline 5 & Chistock 2500 & - & + & + & + & $?$ \\
\hline
\end{tabular}

where: 1 . The presence of T-shaped pipes; 2 . The location pipes directly under the inspection hatches; 3 . Tightness of inspection hatches; 4 . The height of the "mines"; 5. Compliance with the number of bedrooms in the house.

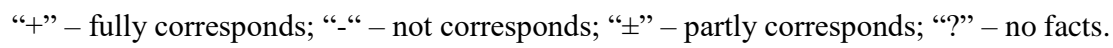

Table 4 fix the existence of materials for measuring the quality of purifying and other parameters in supporting documents.

Table 4. Compliance with documentation requirements.

\begin{tabular}{|c|c|c|c|c|c|c|}
\hline \multirow{2}{*}{$№$} & \multirow{2}{*}{ Name septic tank } & \multicolumn{5}{|c|}{ Requirement } \\
\cline { 3 - 7 } & & 1 & 2 & 3 & 4 & 5 \\
\hline 1 & Carat-S & + & - & - & - & - \\
\hline 2 & Green Rock 05 & \pm & - & - & - & - \\
\hline 3 & YES! & + & + & + & - & - \\
\hline 4 & Tank Universal 2 & + & + & - & - & - \\
\hline 5 & Chistock 2500 & + & - & - & - & - \\
\hline
\end{tabular}

In the table 4: 1. Detailed drawings; 2 . A detailed description of the principles of operation of the product and processes; 3 . Explanations of the main details; 4. Justification for the use of parts; 5. Official documents.

Table 5 help to evaluate the quality of supporting manual of anaerobic septic tank. The received results could be used in the related field of activity [20-24].

Table 5. Compliance with instructions.

\begin{tabular}{|c|c|c|c|c|c|c|}
\hline \multirow{2}{*}{$№$} & \multirow{2}{*}{ Name septic tank } & \multicolumn{5}{|c|}{ Requirement } \\
\cline { 3 - 7 } & & 1 & 2 & 3 & 4 & 5 \\
\hline 1 & Carat-S & - & - & - & - & - \\
\hline 2 & Green Rock 05 & \pm & - & + & + & + \\
\hline 3 & YES! & - & + & + & - & + \\
\hline 4 & Tank Universal 2 & - & - & + & + & - \\
\hline 5 & Chistock 2500 & - & - & + & - & + \\
\hline
\end{tabular}

where: a. Describes which water intake devices could be used and which are undesirable. b. Describes how hot the wastewater should be; c. Approximate frequency of cleaning; d. Features of operation of the product in the winter; e. Chemicals to improve the performance of the product. 


\section{Conclusion}

In this article the main terms and conceptions was defined. There was a short description of operating principle of anaerobic septic tank, its application conditions, advantages, and disadvantages. This article also introduced requirements for anaerobic septic tank's construction as one of the autonomic systems of sewage water treatment. By "value for money" YES! is optimal -with the availability of low cost it achieving $70 \%$ of purifying; with the filtration field (not included in costs) water delivering into soils will be treated on 97\% from organic matter. In case of impossibility of filtration field the best variant is Green Rock 05; complex provides standard sewage treatment if storage is prevented from air supplying and existing the storage for biofilm after biofilter. YES! is the construction with the best quality of tank's work and its maintenance. All the reviewed anaerobic septic tanks have constructive disadvantages making their more difficult to use and decreasing the purifying quality. Some tanks have elements with big cost but low necessity. Materials on web sites of manufacturers are low informative and mostly promoting.

\section{References}

1. M. Hammer, (Izd. Stroiizdat, Moskva, 1979).

2. M. Henze, P. Armoes, J. La-Cour-Jansen, E. Arvan, (Izd. Mir, Moskva, 2004).

3. D. Danilovich, Water supply and sanitary equipment, 3, 6-13 (2012).

4. A. Kunakhovich, Water supply and sanitary equipment, 5, 61-65 (2012).

5. Yu. Voronov, S. Yakovlev, (Izd. Publishing Association of Construction Universities, Moskva, 2006).

6. URL: https://www.avtonomno.ru/articles/dvukhkamernye-septiki/.

7. S. Pavlov, A. Novikov, A. Pavlov et.al., MATEC Web of Conferences, 73, 03005 (2016)

8. M.V.Yates, Groundwater, 23, 586-591 (1985).

9. C.D. Beal, E.A. Gardnev, N.W. Menzier, Australian Journal of Soil Research, 43, 781802 (2005).

10. M. Wagner, A. Loy, Current Opinion in Biotechnology, 13, 218-227 (2002).

11. URL: http://www.greenrock.ru/septik-greenrock-mini-05-s.

12. URL: http://aquaf.ru/septik-carat.

13. URL: http://aquaf.ru/septik-yes.

14. URL: http://www.septiki-tank.ru/catalog/septik-tank-universal/septik-tank-universal-2new.pdf

15. URL:https://www.superseptic.ru/catalog/septiki/chistok/septik_chistok_2500.pdf

16. URL: http://www.graf-voda.com.ua/files/septik_carat_s.pdf.

17. URL: http://www.tpres.ru/assets/files/2017/Flotenk-STA-YES!.pdf.

18. URL: http://www.septiki-triton.ru/bf/tank.pdf.

19. URL: https://tvoy-septik.ru/assets/files/chistok/pasport_chistok.pdf.

20. R.A. Poluektov, V.V. Terleev, Russian Meteorology and Hydrology, 12, 73-77 (2005).

21. A. Makarov, A. Mihailova, N. Arefiev et.al. Procedia Engineering, 117, 225-231 (2015).

22. A. Nikonorov, S. Pavlov, V. Terleev, et.al. Procedia Engineering, 117, 258-263 (2015).

23. V.V. Terleev, A.G. Topaj, W. Mirschel, Russian Meteorology and Hydrology, 40, 278285 (2015). 